\title{
As mutações do conto: das formas simples às narrativas autorais
}

\author{
Murilo Eduardo dos Reis ${ }^{\mathrm{i}}$
}

\begin{abstract}
RESUMO
O tema do artigo são as mutações sofridas pelo conto, das formas simples às narrativas autorais. O objetivo é verificar como essa tipologia narrativa foi alterada com o intuito de atender exigências oriundas do desenvolvimento da imprensa no século XIX, perdendo seu status de relato sagrado e culminando em duas importantes poéticas concebidas por Edgar Allan Poe e Julio Cortázar. Assim, o percurso metodológico se vale de ensaios que tratam de aspectos da narrativa e de características gerais do conto. Além dos autores já mencionados, utilizaremos as proposições de estudiosos como Viktor Chklóvski (2013), Vladimir Propp (2013), Charles Kiefer (2011) e Fábio Lucas (1983). Ao final, espera-se identificar como o espaço limitado de publicações periódicas influenciou contistas na utilização de recursos expressivos que buscam efeitos catárticos.
\end{abstract}

Palavras-chave: Conto; Formas simples; Edgar Allan Poe; Julio Cortázar.

\begin{abstract}
This article focuses on the transformations short stories have been through, from simple forms to authorial narratives. The aim is to verify how this narrative typology was modified in order to meet the demands arising from the development of the press in the nineteenth century, as it loses its status as a sacred report and it culminates in Edgar Allan Poe's and Julio Cortázar's poetics. Thus, the methodological path uses essays that deal with aspects of the narrative and general characteristics of the short story. In addition to the authors aforementioned, we will use the propositions of scholars such as Viktor Chklóvski (2013), Vladimir Propp (2013), Charles Kiefer (2011) and Fábio Lucas (1983). In the end, we expect to identify how the limited space of periodical publications influenced short stories in the use of expressive resources that seek cathartic effects.
\end{abstract}

Keywords: Short story; Simple forms; Edgar Allan Poe; Julio Cortázar.

\footnotetext{
${ }^{\text {i }}$ Doutorando em Estudos Literários, na linha de Teoria e Crítica da Narrativa. Universidade Estadual Paulista "Júlio de Mesquita Filho" - UNESP

ORCID: https://orcid.org/0000-0001-5372-4326 | murilo.reis@unesp.br
} 
Em A arte do conto (1972), Raimundo Magalhães Jr., além de debruçar-se sobre aspectos mais gerais da narrativa curta, propõe-se a esmiuçar algumas de suas vertentes. Se consultarmos o índice da obra, veremos capítulos intitulados "O conto em verso", "O conto fantástico", "O conto moral", "O conto satírico", "O conto policial" etc. Ao contrário de Magalhães Jr., não temos o objetivo de investigar cada uma das ramificações etimológicas. Nosso intuito é refletir sobre características genéricas desse gênero narrativo e a respeito das mudanças que ele sofreu com o advento da imprensa no século XIX, perdendo a pecha de relato ligado a rituais sagrados e assumindo aspectos autorais.

Nesse momento, o conto recebe sua primeira e mais importante poética em resenhas escritas por Edgar Allan Poe. Posteriormente, o escritor Julio Cortázar, um dos mais ilustres leitores do autor de $O$ corvo, compõe textos singulares a respeito das formas breves de narrar. Estabelecemos as proposições do escriba argentino, que dialogam com cinema e a fotografia, como o ponto final das reflexões deste trabalho que, longe de esgotar o assunto, busca contribuir com as discussões a seu respeito. Dito isso, inicialmente, julgamos ser necessário ponderar mecanismos básicos que colocam uma narrativa em movimento.

Em sua "Poética", Aristóteles (2005, p. 26) disserta sobre aspectos elementares da tragédia - a imitação de uma história com começo, meio e fim. Mais adiante, ele (ARISTÓTELES, 2005, p. 29-30) diz que a tragédia não deve ser apenas a simples reprodução de um objeto, mas também algo que inspire temor e pena por meio de fatos inesperados, reviravoltas chamadas de peripécias. Essa definição básica dada ao texto trágico dialoga com a concepção do que é o conto. Tal essência está nas palavras de Alfredo Bosi (2006, p. 7), para quem, comparado à novela e ao romance, o conto faz valer todas as possibilidades da ficção, ficando sempre na fronteira que separa o narrativo do lírico, o diegético do dramático.

Serve de complemento ao raciocínio de Bosi a reflexão de Raimundo Magalhães Jr. Nas palavras do catedrático (MAGALHÃES JR., 1975, p. 10), em comparação ao romance, o conto seria uma narrativa episódica, linear e horizontal, que não se aprofunda na psicologia das personagens, tampouco nos motivos das suas ações. A conduta dos atores é explicada apenas pelos seus modos de agir. Já o romance, ao contrário, não apresenta um único episódio, mas uma sucessão deles. Todos esses 
capítulos são interligados e explorados verticalmente, com uma profundidade que o conto não poderia praticar.

Sobre a distinção que se faz entre conto e romance, Fábio Lucas segue a mesma linha de Bosi e Magalhães Jr. Conforme a análise do crítico (LUCAS, 1983, p. 105), enquanto a narrativa longa, por conta das complexidades e das metamorfoses das personagens, torna-se espelho da multiplicidade de relações da sociedade, a breve tende a captar o individual, ou seja, um momento específico da trajetória humana.

Porém, para que os críticos chegassem a essas concepções, a roda da História girou bastante. $\mathrm{O}$ conto demorou a atingir maturidade literária e adquirir características palpáveis como as da tragédia aristotélica. Nádia Battella Gotlib (1985, p. 6-7) detecta fases que passam por Caim e Abel na Bíblia, pelas narrativas de Sheherazade nas Mil e uma noites e chegam ao século XIV, quando o conto transmitido oralmente ganha registro escrito e o estatuto de histórias de moldura nas narrativas do Decameron, de Bocaccio. Depois, surgem as Novelas exemplares de Cervantes no século XVII, as fábulas de La Fontaine no XVIII.

Mas é no século XIX que o conto se desenvolve, principalmente, pela pesquisa do popular e do folclórico (tendo como principais representantes Jacob e Wilhelm Grimm) e pela explosão dos veículos de imprensa. Foi nesse momento, afirma Magalhães Jr. (1975, p. 14), que a forma breve atingiu certa excepcionalidade, representada por nomes como Ernst Theodor Wilhelm Hoffman na Alemanha, Gustave Flaubert e Guy de Maupassant na França, Anton Tchekhov na Rússia, Edgar Allan Poe nos Estados Unidos, Machado de Assis no Brasil.

Dada a complexidade evolutiva do conto, julgamos necessário refletir sobre as formas que serviram de base para o tipo de narrativas curtas que temos hoje. Apesar de sua aparente simplicidade, são modelos que resistiram ao passar dos anos.

\section{FORMAS SIMPLES}

Antes de a narrativa literária receber o nome que conhecemos, Aristóteles (2005, p. 19) a definiu como arte que utiliza apenas palavras. Em comparação à poesia, não dispõe de metrificação fixa ou de ritmo. O mesmo filósofo (ARISTÓTELES, 2005, p. 20) também diz que há manifestações artísticas que combinam meios expressivos 
(ritmo, melodia, metro) e diferem por ora utilizarem todos a um só tempo, ora somente um ou dois deles. Dessa maneira, pode-se dizer que é preciso considerar os recursos de significação de cada arte e a miscelânea que movimenta as engrenagens da imaginação do enunciatário, tendo como resultado o surgimento de ideias.

É possível que relacionemos esse aspecto trazido por Aristóteles com as reflexões de Victor Chklóvski sobre arte. O formalista russo (CHKLÓVASKI, 2013, p. 83-85) escreve que a arte é o pensamento por imagens e que as artes poéticas não passam de imagens tomadas de empréstimo de antigos autores pelos novos. O trabalho das escolas literárias é constituído pela acumulação e revelação de novos procedimentos que têm como objetivo mais dispor do que criar reproduções. Os objetos revelados por essas figuras podem ser confeccionados de diferentes maneiras, e cada uma delas depende do emprego dos recursos expressivos mencionados por Aristóteles.

A partir daí, Chklóvski (2013, p. 86) ressalta que o objeto pode ser prosaico e percebido como poético ou vice-versa, sendo seu caráter estético dependente da maneira como ele é percebido. Tal percepção está sujeita a procedimentos particulares que garantem ao item descrito a mencionada estética. Apesar de a descrição ser fundamental para que o destinatário da mensagem a perceba artisticamente, cabe ressaltar que ela não deve ser feita de maneira cotidiana, pois, segundo Chklóvski (2013, p. 87), a finalidade da arte é dar ao objeto status de visão, singularização daquilo que é normalmente apenas reconhecido por seu utilitarismo.

Entre os mecanismos utilizados para a criação imagética, a metáfora certamente é um dos mais recorrentes. Em passagem de ensaio sobre as principais características da obra de Kafka, Modesto Carone (2011, p. 16) registra que o ingrediente metafórico é algo, segundo Ernst Cassierer, imprescindível para a linguagem em geral, e não somente à literária. O ensaísta e tradutor brasileiro (CARONE, 2011, p. 16-17) explica que muitas delas foram assimiladas pelo dia a dia (braço de mar, preço de banana, perna de cadeira) e por isso perderam seu impacto. Kafka, ao utilizar metáforas, não se interessa por elas em si, mas pelo efeito artístico causado por suas combinações, pois queria que sua literatura fizesse doer como um estilete cravado na carne. Sendo tão afeita a conjuntos de metáforas, Carone (2011, p. 17) vê a obra do escritor tcheco como um encadeamento de imagens. Porém, não meras imagens, pura e simplesmente. É recorrente a confusão que se faz ao diferenciar metáfora e metonímia. Sobre esse tema, 
Gérard Genette (2017, p. 30) retoma as palavras de Boris Eichenbaum e faz a seguinte distinção: a metáfora está para a poesia (o ouro e o trigo), enquanto a metonímia equivale à prosa (o ferro e a espada). Ou, como o próprio Genette (2017, p. 43) simplifica posteriormente, o cruzamento por semelhança está para a metáfora, enquanto a proximidade ou a justaposição, para a metonímia.

Ainda sobre as "dores" causadas pela arte, uma personagem da novela A obraprima ignorada (2012), de Honoré de Balzac, reflete sobre os efeitos causados por uma boa pintura. Ao analisar uma tela confeccionada por seu aprendiz, detecta que a imagem não transmite vida ao expectador, pois está próxima a padrões encontrados no mundo real. Diante da incredulidade do aluno, explica que, para ser um bom poeta, deve-se ir além dos usos corretos das regras de sintaxe. A missão da arte, continua ele, não é copiar a vida, mas expressá-la, e o poeta não deve ser um mero copista daquilo que observa. É necessário captar os efeitos contidos na fisionomia, na alma, no espírito das coisas. Esses efeitos seriam os acidentes da vida, não a vida em si.

$\mathrm{O}$ conto sempre esteve associado à criação de imagens e à sua consequente singularização. $\mathrm{O}$ ato de contar histórias é quase tão velho quanto o ser humano. Sobre esse aspecto, Magalhães Jr. (1972, p. 9) escreve que, além de ser a forma mais antiga de ficção, é também a mais geral, pois existe mesmo entre povos que não detêm o conhecimento da escrita. Por meio da oralidade, narram-se histórias ingênuas e pouco complexas de bichos, lendas e mitos. Já Nádia Battella Gotlib (1985, p. 5) lembra que, sob o signo da convivência, histórias atraem continuamente narradores e ouvintes, seja em volta da fogueira ou ao redor da mesa de jantar, após um dia de caça ou de trabalho. Para prender a atenção de suas plateias, é necessário aos detentores da palavra saber manipulá-la e descolá-la do discurso monótono e cotidiano. Devem criar imagens singulares, portanto.

Corroborando as ideias de Magalhães Jr. e de Gotlib, Charles Kiefer (2011, p. 301) esclarece que, no início, o suporte abstrato do conto foi a memória e que ela foi seu principal vetor. É nesse longínquo passado que a narrativa breve configurou a essencialidade como sua característica mais substancial e eficaz. Kiefer (2011, p. 301) ainda lembra que sua matéria-prima básica era constituída pela vida prática ou pelo fabulário mítico. Por centenas de anos, as histórias oriundas dessa receita continham teor moral, pedagógico e religioso, configurando um caráter exemplar. O pesquisador 
(KIEFER, 2011, p. 301) conclui que, se a tragédia transformou-se no drama e a epopeia metamorfoseou-se no romance, a história curta, seja ela popular ou erudita, manteve seu alicerce original: brevidade, unidade e totalidade.

Pensando no modo tradicional de relatar acontecimentos fictícios, Walnice Nogueira Galvão (1983, p. 167) reflete sobre a figura do contador de histórias, depósito de memória da comunidade que é responsável por garantir que conhecimentos milenares continuem transitando entre gerações. A ensaísta (GALVÃO, 1983, p. 167) assevera que esse sujeito é uma espécie em extinção, já que o ritmo de trabalho das sociedades industriais não disponibiliza tempo para os ritos coletivos. Uma fala do escritor moçambicano Mia Couto ilustra bem a importância dos anciões para determinados grupos. Em entrevista concedida ao programa Roda Viva realizada no ano de 2012, o autor de Terra sonâmbula afirma que, em Moçambique, há o seguinte ditado: quando um velho morre, uma biblioteca arde.

Ao escrever sobre a coletânea Três contos, do escritor moderno Gustave Flaubert, Italo Calvino (2007, p. 163) sublinha que a palavra conto, alinhando-se às reflexões dos estudiosos supracitados, apela à narrativa oral, ao maravilhoso, à fábula. Adicionando a legenda, o mito, a saga, a adivinha, o ditado, o caso e o chiste às formas de narrar destacadas por Calvino, Gotlib (1985, p. 17-18) cita André Jolles, para quem o conto é uma forma simples que permanece através dos tempos e que é recontada por vários indivíduos, de diferentes gerações. Ainda a respeito do aspecto evolutivo das formas de narrar, Fábio Lucas (1983, p. 106) também recorre aos modos tradicionais citados por Jolles e, para efeito de comparação, menciona como o romance foi modificado no decorrer do tempo. Assim como Charles Kiefer, Lucas (1983, p. 106) diz que, grosso modo, o romance é herdeiro remoto da epopeia que, de maneira moderna, provém da História, dos relatos de viagens e colonizações, enquanto o conto tem suas raízes ligadas às narrativas domésticas e moralizantes, tais como as elencadas por Gotlib.

Essas formas fixas se opõem às artísticas, aspecto atribuído aos relatos criados por autores específicos. Seguindo essa linha de raciocínio, Gotlib (1985, p. 17) menciona Julio Casares, que entende o conto como uma fábula que se conta às crianças, ligando-o ao maravilhoso, com personagens não determinadas historicamente. Tais narrativas trazem em seu núcleo "as coisas como deveriam ser", pois satisfazem as 
expectativas do leitor e contrariam o mundo real, lugar onde os fatos nem sempre ocorrem da forma como gostaríamos.

Nosso objetivo aqui não é dissecar todos os gêneros discursivos classificados por André Jolles como simples. Por isso, vamos nos deter em dois deles, os quais consideramos ser mais recorrentes em nossa sociedade e em outras, principalmente as localizadas no lado ocidental do globo.

Vladimir Propp (2013, p. 271) compara o estudo dos contos maravilhosos ao das formas orgânicas da natureza, pois tanto o folclorista quanto o naturalista lidam com fenômenos particulares que, na sua essência, são idênticos. A partir de seus estudos, Propp (2013, p. 272) afirma que, embora diferentes na aparência, na idade, no estado civil, no sexo e na ocupação, as personagens das histórias maravilhosas executam ao longo da narração os mesmos atos, determinando a relação das constantes com as variáveis. Desse modo, o estudioso expõe a seguinte sequência:

1. O rei envia Ivan para procurar a princesa. Ivan parte.

2. O rei envia Ivan para procurar um objeto singular. Ivan parte.

3. A irmã envia o irmão para procurar um remédio. O irmão parte.

4. A madrasta envia a enteada para buscar fogo. A enteada parte.

5. O ferreiro envia o aprendiz para procurar a vaca. $\mathrm{O}$ aprendiz parte. (PROPP, 2013, p. 272-273)

Sobre as sequências enumeradas, nota-se que se organizam em torno de verbos conjugados no presente (envia, parte), além de contarem com orações subordinadas substantivas reduzidas de infinitivo (para procurar a princesa, para procurar um objeto singular), que correspondem à função do sujeito que recebe a ordem dentro da história. Não são exatamente cenas, mas ações executadas, sem descrições espaciais nem aprofundamento na psicologia das personagens. Funcionam quase como rubricas de textos teatrais.

Propp (2013, p. 273) identifica como constantes os envios e as partidas, enquanto as motivações e os indivíduos seriam as variáveis. As etapas das buscas e seus respectivos obstáculos igualam-se na essência, sem coincidir na aparência. $\mathrm{O}$ formalista (PROPP, 2013, p. 273) lembra as trinta e uma funções do conto maravilhoso que ele próprio enumerou. Apesar de nem sempre os contos apresentarem todas as funções, a ausência de algumas delas não influencia na ordem e na sucessão das outras. Assim, tem-se um sistema composicional estável e difundido. 
Atestando a simplicidade observada por Jolles e as recorrências analisadas por Propp em narrativas milenares tidas como simples, Maria Celeste Consolin Dezotti (2018, p. 23-24) aborda outra tipologia ficcional: a fábula. A autora explica que se trata de um modo universal de construção discursiva, variando de um povo a outro, de acordo com suas respectivas culturas. Segundo ela (DEZOTTI, 2018, p. 24), a narração da fábula está sempre a serviço da censura, da recomendação, do aconselhamento, todos eles atos ligados à fala. Tal simplicidade formal estaria associada, diz a autora (DEZOTTI, 2018, p. 24), à resistência do gênero ao avanço da História.

Sendo a fábula um discurso, uma ação de fala, Dezotti (2018, p. 25), embasada no raciocínio de Alceu Dias Lima, assinala que são articulados três eixos discursivos: um narrativo, um interpretativo ou moral, e um metalinguístico. Para melhor elucidar o funcionamento desse sistema, a pesquisadora destaca a versão esópica de "O lobo e o cordeiro":

\begin{abstract}
Um lobo viu um cordeiro bebendo água de um rio e desejou devorá-lo por um motivo qualquer e bem pensado. Por isso, tendo se postado mais acima, pôs-se a acusá-lo de turvar a água e de impedi-lo de beber. Então o cordeiro disse que bebia na ponta dos lábios e que, além do mais, não podia ser que ele, que estava mais abaixo, estivesse turvando a água de cima. Vencido nessa acusação, o lobo disse: "Mas no ano passado você injuriou meu pai!". E como o outro dissesse que naquela época nem era nascido, o lobo lhe disse: "Mesmo que você se saia bem na defesa, eu não vou deixar de te comer!". A fábula mostra que, junto daqueles cujo propósito é praticar a injustiça, nem uma justa defesa prevalece. (ESOPO apud DEZOTTI, 2018, p. 25-26)
\end{abstract}

Pensando nas concepções relacionadas à arte literária e à sua consequente criação de imagens, podemos perceber que a cena é criada de maneira objetiva. $O$ entrelaçamento de verbos conjugados no pretérito perfeito (viu, desejou, disse) com orações subordinadas substantivas (o cordeiro disse que bebia na ponta dos lábios), adverbiais (tendo se postado mais acima, vencido nessa acusação) e adjetivas (não podia ser que ele, que estava mais abaixo) nos dão o enquadramento exato das ações, dos comportamentos e da localização das personagens no espaço que as circunda. Todos esses elementos são organizados por um narrador que, onisciente, relata o desenrolar da trama em terceira pessoa.

Dezotti (2018, p. 26) afirma que esse texto de dois parágrafos apresenta a estrutura típica de uma fábula. No primeiro bloco, temos a narrativa; no segundo, o epimítio - de acordo com os autores do Dicionário Houaiss da língua portuguesa 
(HOUAISS; VILLAR, 2009, p. 783), trata-se de uma frase final, máxima que sintetiza o ensinamento de uma fábula ou qualquer texto literário breve. A autora (DEZOTTI, 2018, p. 26) escreve que a última parte se constitui de duas linhas de raciocínio: a interpretativa ("junto daqueles cujo propósito é praticar a injustiça, nem uma justa defesa prevalece") e a informativa, que diz respeito à ação da fábula ("A fábula mostra"). Assim, a interpretação diz respeito à moral, enquanto a reflexão sobre o que está sendo realizado é metalinguística.

É possível notar, por intermédio das análises de Propp e Dezotti, que, apesar de abordarem situações com personagens e temáticas variadas, os contos maravilhosos e as fábulas conservam em seus cernes aspectos discursivos recorrentes, características fixas que os afastam do conceito de autoria. Retomando o raciocínio do formalista russo, podemos dizer que o conto, assim como as espécies biológicas, evoluiu e, a partir do século XIX, atingiu a maioridade, passando a ser imprevisível.

\section{A DERROCADA DO RELATO SAGRADO}

Como dissemos pelas palavras de Charles Kiefer (2011), antes de ser produto de consumo de uma sociedade em busca de distração, a arte de contar histórias sempre esteve associada a rituais de passagem ou religiosos. Nadia Battella Gotlib (1985, p. 23) menciona que, além de ter identificado recorrentes funções nos contos maravilhosos, Propp também pesquisou suas origens. Nesse trabalho, o estudioso formalista teria encontrado duas importantes fases evolutivas.

A primeira diz respeito à pré-história, em que o conto e o relato sagrado (mito, rito) se confundem. Aqui, entende-se mito por narrativas sobre divindades, em cuja existência determinado povo crê. O rito estaria associado a costumes ou cerimônias praticados por determinados grupos. Gotlib (1985, p. 24) explica que, nessa fase religiosa, os velhos narravam aos jovens suas origens, explicando o motivo de algumas proibições e de atos aos quais as novas gerações eram submetidas. O relato, então, estava intrinsicamente ligado ao ritual religioso, sendo proibido narrar certas histórias fora das cerimônias, pois tal procedimento estava mergulhado em funções mágicas e não poderia ser realizado por qualquer pessoa. 
Gotlib (1985, p. 24-25) escreve que a segunda fase identificada por Propp é o momento em que o contar histórias se descola dos ritos religiosos e passa a ter autonomia. Dessa maneira, os relatos sagrados abandonam seu atributo original e passam a ser profanos, perdendo a denotação religiosa. Antes narrados apenas por sacerdotes, passam a ser manipulados por pessoas quaisquer. Mais uma vez, a pesquisadora (GOTLIB, 1985, p. 25) se ancora a Propp para sublinhar que, nesse momento, livre das imposições religiosas, o conto é submerso na atmosfera da criação artística e passa a ser impulsionado por outros fatores sociais.

Contudo, apesar de ter ganhos nos âmbitos artístico e autoral, vale meditar sobre aspectos que, de alguma maneira, não parecem tão positivos quando se trata de aprendizagem e compartilhamento de saberes. Por isso, retomamos as palavras de Walnice Nogueira Galvão (1983, p.167) localizadas no início deste artigo, por meio das quais a autora de Saco de gatos reflete sobre a figura do contador de histórias, eclesiástico ameaçado de extinção pelo ritmo alucinante das sociedades industriais. Em tais contextos, já não há mais tempo para rituais coletivos, para ouvir antigas narrativas que expliquem imposições do presente. Como assinala Walter Benjamin (2012, p. 213), em um mundo marcado pelas experiências individuais, é cada vez mais frequente o constrangimento de quem manifesta o desejo de ouvir histórias à moda antiga. Assim, esse sujeito é privado de sua faculdade de trocar conhecimentos.

A partir do século XIX, essa transição torna-se ainda mais evidente. Charles Kiefer (2011, p. 14) assinala que a variante ocidental do conto nasceu com o surgimento da imprensa, da locomotiva e da industrialização. A respeito disso, Fábio Lucas (1983, p. 105) afirma que o conto constitui o gênero literário que mais se adequou às especificidades dos tempos modernos, acompanhando a evolução da imprensa e das publicações periódicas. Já Nogueira Galvão (1983, p. 168-169) assegura que o gênero das histórias breves estabelece a tomada do poder literário por meio da prosa ficcional impressa nos jornais. Assim, a ficção passa a competir com os fatos trazidos pela notícia e estabelece uma interessante contradição entre o factual e o imaginário, em que um quer ser o outro.

Nogueira Galvão (1983, p. 168) ainda fala que o conto se apresenta como uma das primeiras investidas da indústria cultural, um braço do capital conectado à cultura, dentro de uma imprensa mantida por anúncios publicitários. Nessa mesma linha de 
pensamento, Kiefer (2011, p. 18) ressalta que, nesse período, por uma emergência interna, o capitalismo massifica a educação e as pessoas têm cada vez mais necessidade de entretenimento nas horas livres. A energia elétrica fez a noite mais curta, dias santos e feriados foram criados, o tédio característico das áreas rurais foi transferido para as grandes cidades. Por isso, complementando o raciocínio de Fábio Lucas (1983) acima exposto, há uma explosão de revistas de variedades que comportam seções literárias, comprovando que o sistema literário se movimenta cada vez mais rápido, imitando o ritmo frenético das rotativas. Esses suplementos publicam novos autores, as editoras lançam antologias que são resenhadas nos periódicos, gerando novos leitores e resenhistas.

Sobre a velocidade cada vez maior com que a imprensa se movimenta, forma leitores e lança escritores, cabe lembrar a menção que Flora Süssekind (1987, p. 12) faz sobre a cena inicial do filme Hammett. Nela, o diretor Wim Wenders mostra o personagem-título, que, de costas para a janela, datilografa de maneira frenética. Tratase de um escritor que, sem fazer rascunhos, escreve direto à máquina textos de imediata publicação em revistas baratas, em ritmo industrial de produção.

Nessa sociedade urbana que se torna cada vez mais veloz e tecnológica, Fábio Lucas (1983, p. 106) faz saber que o Realismo, signo desse mundo de aço e de concreto, cristalizou determinado modelo de conto que, por causa de sua condensação e do rigor aplicado ao seu acabamento, passou a ser comparado ao soneto. Nesse tipo de narrativa, todas as partes se organizam em prol de um desfecho. Guy de Maupassant, por exemplo, foi dos escritores cuja obra é mais comparada a essa vertente poética com metrificação e formas fixas. Noemi Moritz Kon (2009, p. 17) descreve o escritor francês, discípulo de Flaubert, como um contista exímio, especialista em descrições da natureza e dos gestos humanos. A mesma estudiosa ainda sublinha que, longe de exibir a imparcialidade peculiar aos relatos naturalistas, a obra de Maupassant, por meio de estética jornalística, dirige nosso olhar para aquilo que dá sentido à realidade, ao peculiar e singular. Assim, revela paixões e sofrimentos, que são as engrenagens básicas que movem os homens.

Esse conto publicado em jornais e revistas, por razão dos modos como é estruturado, acaba ganhando duas novas nomenclaturas. Mantendo similaridades com o romance nos aspectos narrativos e especificando-se pela condensação dos meios ou pelo 
feitio de uma anedota, sua feitura tem algo de similar ao drama, já que seu maior interesse é conduzir as ações de modo que elas culminem em um desenlace das tensões construídas ao longo do texto, escreve Lucas (1983, p. 107).

Considerando o aspecto dramático, é possível conectar o conto à estrutura das tragédias solidificadas por Aristóteles. O filósofo (ARISTÓTELES, 2005, p. 24) estabelece as histórias trágicas como representações graves e completas que, por meio de linguagem adequada e da ação dos atores, exerce a catarse própria de certos sentimentos. Todas as ações da tragédia, assevera Aristóteles (2005, p. 25-26), organizam-se em favor daquele que é seu objetivo maior, ou seja, a catarse que visa inspirar pena e temor. Tal é o efeito do que se nomeia peripécias e reconhecimento.

Em suma, a tragédia é a imitação de uma ação. Essas características da narrativa trágico dramática aproximam-na do que Fábio Lucas (1983, p. 110) chama de conto de enredo. Utilizando as palavras de A. L. Bader, Lucas descreve o mecanismo dessa vertente como essencialmente vinculado à tragédia, já que, desde a primeira linha, o leitor é conduzido por uma sequência de acontecimentos que comporta a declaração explícita ou sugestiva de um conflito. Temperadas por mistério e tensão, as ações no interior desse embate levam o espectador à crise e à resolução final. Nogueira Galvão (1983, p. 169), por sua vez, analisa a forma do conto de enredo como essencialmente informativa, mais próxima do jornalismo do que da literatura, algo similar ao estilo de Maupassant.

Como oposição ao conto de enredo, Lucas (1983, p. 107) estabelece o conto de atmosfera, que surgiu a partir do desmanche de intrigas e da desconvencionalização de caracteres, aspectos que sempre acompanharam o que se chama de ficção moderna. Nesse tipo de conto, há maior atenção para referenciais menos externos ao texto e mais voltados para os processos narrativos, fazendo com que seu gradiente literário se aproxime da expressão lírica. Por isso, essa tipologia narrativa se distancia da rigorosa estrutura dramática e da explosão proporcionada pelo clímax. Lucas (1983, p. 108-109) explica que a dramatização estática reduz a ação externa ao mínimo, estabelecendo uma poética que se liga à obra de Tchekhov. Mais do que a cena que encerra o relato, o que importa é o modo como o corpo do texto é estruturado. Esse tipo de expressão foi também o modus operandi de autores como Franz Kafka, Katherine Mansfield e Clarice Lispector, cujos escritos remontam às estéticas de vanguardas europeias como o 
impressionismo e o expressionismo. Suas teias narrativas se organizam em torno de um único incidente, que é trabalhado com ironia e delicadeza de estilo. Os atores mais adequados à narrativa de atmosfera, conclui Lucas (1983, p. 109), são aqueles menos ligados à ação do que à consciência. Os espaços em que a história é encenada são circunscritos e fechados, o que possibilita adentrar suas intimidades.

Nesse contexto em que o conto incorpora procedimentos que o tornam mais complexo, Edgar Allan Poe publica resenhas e cria a primeira poética do conto. Como veremos a seguir, ao contrário de Tchekhov, o escritor estadunidense ajunta às suas reflexões procedimentos que aproximam seus escritos do conto de enredo, vertente que preza pelo efeito causado a partir do desenlace.

\section{EDGAR ALLAN POE}

Quando se ouve o nome de Edgar Allan Poe, é provável que a maioria dos leitores o associem a contos de terror como "O gato preto", "Berenice", "O poço e o pêndulo" e "A queda casa de Usher". Além de ser associado ao terror, é consenso entre grande parte dos estudiosos que Poe inaugurou o formato do romance policial moderno. No decorrer da história da literatura, há outros exemplos em que uma personagem se mostra disposta a realizar a montagem de um quebra-cabeça à maneira do que mais tarde seria batizado de detetive. Porém, é a partir de "Assassinatos na Rua Morgue”, "O mistério de Marie Rôuget” e "A carta roubada" (três narrativas protagonizadas pelo excêntrico Dupin e narradas das mesmas distância e perspectiva) que autores como Arthur Conan Doyle e Agatha Christie encontraram a base para as suas próprias produções artísticas.

Esses fatos levam Jorge Luis Borges (2011, p. 51) a ser categórico ao afirmar que falar sobre o relato policial é falar de Edgar Allan Poe, que, em sua opinião, é o inventor do gênero. Borges (2011, p. 53-54) ainda diz que esse formato de histórias inaugurado por Poe leva em consideração o fato de a literatura ser uma operação da mente e não do espírito. Enfim, é um tipo de texto que fez e ainda faz muito sucesso comercial, situação que é facilmente comprovada pela quantidade de séries e de filmes policiais que habitam os canais de televisão, as plataformas de streaming e os cinemas. 
Entretanto, Edgar Allan Poe não foi somente artista, mas também um crítico e escritor atento à sua época. Ciente da mecanização dos meios de comunicação e de um tempo que se torna mais escasso em favor de maior produtividade, Poe percebe que textos em prosa devem ser estruturados de maneira que atendam tais demandas. Essas reflexões aparecem em três resenhas que o autor de $O$ corvo publica sobre a coletânea Twice-told tales, de Nathaniel Hawthorne. Nelas, ele examina os procedimentos artísticos e indica, em alguns casos, o melhor tratamento dos meios expressivos.

Charles Kiefer (2011, p. 18-19) resume bem o modo como Poe pensa as narrativas que serviriam para tirar o tédio do homem moderno. Elas deveriam ser histórias curtas, de temática variada, originais, com extensão suficiente para que a leitura fosse realizada numa viagem de trem de Boston a Nova York. Além disso, o espaço reduzido nas páginas de jornais e revistas obriga que o autor realize apurado polimento na linguagem. É necessário economizar nos verbetes, afinal, tempo é dinheiro. A economia gramatical também deve se adequar ao tom da narrativa, e o texto, formado de frases rápidas e parágrafos leves, necessita ser um espelho da agitação urbana. Sobre a questão da forma e dialogando com as questões trazidas por Kiefer, Nogueira Galvão (1983, p. 169) explica que os espaços desses veículos da imprensa em que os textos ficcionais são publicados possuem pouca propensão a vanguardismos, o que obriga os autores a primarem por uma linguagem mais fluida e acessível.

Foram essas condições que delimitaram as regras para a criação de contos eficientes e impactantes. Tendo como base um ensaio de Valdemar Cavalcânti, Magalhães Jr. (1975, p. 20) destaca que, para o conto valer como peça de alto gradiente literário e resistir à passagem do tempo, o texto deve atender a certos aspectos sintéticos e dinâmicos com os quais se recorta uma fatia da vida. À maneira de um fotógrafo (e essa comparação será muito cara à poética de Julio Cortázar, como veremos mais adiante), o contista deve reduzir o foco de sua objetiva e limitar ao máximo a área de observação. Ao contrário do que ocorre no romance, no conto, o que é supérfluo faz a vista doer, como se fosse um inchaço.

Como mencionamos anteriormente, Poe escreveu três ensaios sobre os textos que compõem a coletânea Twice-told tales, de Hawthorne. Eles foram publicadas entre 1842 e 1847 na Graham's Magazine. Pode-se dizer que é no segundo e no terceiro 
artigo que ele melhor desenvolve seu raciocínio a respeito das características que devem acompanhar um conto, além de versar sobre métodos de composição.

Em sua segunda contribuição, que foi lançada em maio de 1842, um mês depois da primeira, o autor estadunidense (POE, 2011, p. 333) ressalta que nem todas as peças encontradas em Twice-told tales podem ser vistas como contos, pois muitas delas são ensaios puros.

Sabe-se que a forma ensaística também é objeto de discussão entre inúmeros teóricos. Umas das mais conhecidas ponderações é a de Theodor Adorno. O filósofo alemão (ADORNO, 2003, p. 29-30) escreve que o ensaio é um processo de experiência intelectual em que o pensamento não avança em sentido único. Diferentes reflexões devem se cruzar como se costurassem um tapete. Terminado o produto, é possível conferir se a tessitura do texto possui densidade. Para Adorno (2003, p. 37), a ensaística se aproxima da arte na medida em que é antissistemática, pois subverte paradigmas de gênero.

A partir das palavras de Adorno, nota-se que o ensaio se encontra a considerável distância do conto, principalmente no que se refere ao efeito. Lendo os sketches de Hawthorne, Poe (2011, p. 334) os avalia como belos, e que um pintor que tomasse contato com eles diria que aquele tipo de beleza pode ser classificado como repouso. Ou seja, tudo é quieto e contemplativo, estando ausente qualquer intenção de atingir algum resquício de efeito. Para o Poe articulista (2011, p. 334), apesar de haver imagens inusitadas, elas nunca excedem a barreira da quietude.

Em sua terceira resenha, trazida a público em novembro de 1847, Poe aprofunda os conceitos trabalhados nos artigos anteriores, englobando também o livro de contos Mosses from an old manse, então mais recente obra de Hawthorne. Nesse ensaio, o autor de "Assassinatos na Rua Morgue" retoma a questão do efeito, que, para ele (POE, 2011, p. 355), seria o aspecto mais importante na composição ficcional. É a partir dele que se tem a sensação de originalidade, algo evocado pelo surgimento de fantasias vacilantes e semiformadas. Poe (2011, p. 358-359) ensina que a alegoria é um dos elementos que mais atrapalham a unidade de efeito, pois ela remete a informações que estão fora da malha textual, prejudicando o desenvolvimento dos temas localizados no seu cerne. A unidade de efeito seria o bem mais valioso do artista, mais vital do que qualquer alegoria, cuja presença inutiliza a seriedade e a verossimilhança da narrativa. 
É nessas páginas de 1847 que Poe também defende a brevidade das narrativas literárias. Para ele (POE, 2011, 361-362), não é a extensão de uma obra que lhe garante qualidade. É justamente o espaço limitado do conto que propicia ao artista o desenvolvimento do pleno domínio da prosa, pois o seu valor está no raio de ação do excitamento. Esse raciocínio dialoga com o de Chklóvski. Embasando-se nas ideias do filósofo Herbert Spencer, o formalista (2013, p. 88) faz saber que a economia da atenção está na base das normas que determinam a escolha e o uso das palavras. O único objetivo de todo e qualquer escritor é criar imagens a partir do caminho mais fácil, utilizando o mínimo de recursos verbais.

Sobre a extensão das narrativas e suas respectivas consequências, Poe (2011, p. 364-365) esclarece que a leitura de um romance longo, que não pode ser lido de uma assentada, coloca para escanteio os benefícios da totalidade, pois a interrupção do contato com a história quebra a unidade. No conto breve, formula Poe (2011, p. 365), o autor conduz por inteiro seu propósito narrativo e, durante esse período, tem em suas mãos a alma daquele que o lê. Em sua visão, antes de inserir quaisquer incidentes na história, o competente artista literário concebe cuidadosamente um efeito único e singular. Depois, combina-o a incidentes que levarão à sua construção, cada frase sendo escrita em favor desse desígnio pré-estabelecido.

Podemos perceber que Edgar Allan Poe, nessas três resenhas, reflete sobre a composição de contos apenas como crítico e ensaísta que procura ver nos escritos de terceiros as qualidades que considera imprescindíveis em boa literatura. Além disso, todas as regras impostas pelo Poe ensaísta dialogam, como dissemos, com o ritmo de uma sociedade que se industrializa em alta velocidade. Mas é no talvez mais famoso de seus ensaios que ele assume a postura de um artista que metrifica sua arte e calcula cada movimento a ser executado. Publicado em 1846 na mesma Graham's Magazine em que escreveu as resenhas sobre os contos de Hawthorne, "A filosofia da composição" é o tratado em que Poe explica o modo como pensou e realizou cada verso de $O$ corvo. Apesar de tratar-se de um poema, suas proposições se encaixam também no processo de elaboração de narrativas breves. Em primeira pessoa, ele reflete sobre a escolha e a combinação de todos os elementos expressivos que constituem o efeito desejado.

Assim como na segunda e na terceira resenhas, lançadas respectivamente em 1842 e 1847, o artista Edgar Allan Poe (2019, p. 58) detém-se primeiramente sobre o 
efeito, que deve ter em vista a originalidade. Após selecioná-lo, pensa na combinação dos incidentes e no tom narrativo, que cumprirão seu desígnio. Ele (POE, 2019, p. 60) volta a dissertar sobre a extensão da obra de arte, que, no caso de ser muito longa, prejudica a criação do efeito e a continuidade da tensão, elementos importantes para a unidade de surpresa - caso sejam necessárias duas sessões de leitura, o sentimento de totalidade se perderá por completo.

As ideias do Edgar Allan Poe artista dialogam diretamente com o que trouxemos no início desse capítulo, tendo como base as palavras de Viktor Chklóvski (2013) e Modesto Carone (2011). Ambos os ensaístas militam a favor da criação de imagens que, por meio do uso de determinados elementos expressivos, subvertem a linguagem cotidiana e perfuram o leitor como se fosse lâmina. O efeito, mencionado por Poe tantas vezes, tem exatamente a função desse estilete que tira o espectador do automatismo. Por isso, o fundador do romance policial moderno se refere reiteradamente à extensão das obras de arte. Para ele (POE, 2019, p. 61), no caso de criações literárias como o poema e o conto, o limite diz respeito a leituras que se realizem em linhas temporais demarcadas. Dentro dessa circunscrição, deve-se estabelecer uma afinidade matemática entre a extensão do texto e grau de efeito catártico que ele é capaz de atingir. Portanto, a partir das palavras de Poe, pode-se dizer que a beleza tem medida.

Não somente a fórmula das narrativas policiais criada por Poe teve inúmeros seguidores. Sua poética do conto também foi objeto de leitura e releitura de muitos. Entre eles, Julio Cortázar certamente foi um dos que mais teve destaque.

\section{JULIO CORTÁZAR}

Julio Cortázar foi um leitor atento de Edgar Allan Poe. Não somente do contista ou do poeta, mas também do crítico que se dedica a esmiuçar os processos de criação artística. Assim, ao ler suas resenhas a respeito da obra de Hawthorne, Cortázar (2008, p. 121) constata que, para o autor de "O gato preto", os processos formais caros à poesia não se enquadram no conto, e as narrativas estéticas não são contos genuínos, sendo esses somente os denominados "de efeito".

A partir das palavras de Cortázar, percebemos que Poe não valoriza o conto de atmosfera, tipo narrativo que nós, anteriormente, destacamos por meio das reflexões de 
Fábio Lucas (1983). As sintaxes impressionistas de escritores como Tchekhov e Mansfield, que apelam mais para o sensorial, não são compatíveis com o efeito buscado por Poe, algo que deve arrebatar o leitor.

Interpretando o modo como Poe se refere à unidade de efeito, o escritor argentino (CORTÁZAR, 2008, p. 123) chega à conclusão de que, no interior das histórias curtas, as coisas devem ser intensas. Para que tal intensidade ocorra (e veremos que essa palavra será muito cara a Cortázar na confabulação de sua própria poética), é preciso que a relação entre forma e conteúdo seja orgânica; o conto não é intenso pelo exagero factual, mas por apoiar o tema na estrutura que o sustenta.

Exemplo dessa organicidade aparece em "Assassinatos na Rua Morgue". Cortázar (2008, p. 127) explica que Dupin se utiliza de matiz analítica para deleitar-se falando de um acontecimento cujo tema é o homicídio grotesco de mãe e filha, que tiveram seus corpos espancados e mutilados. Em toda a sua obra, é dos poucos momentos em que Poe imprime o encanto intelectual por meio do relato cruel. Essa crueldade é atingida pela combinação de tom narrativo (tratar do assunto de modo científico) e de coisa narrada (um assassinato em que a mãe é encontrada presa na chaminé e de cabeça para baixo, e a filha, semidegolada).

Esses aspectos mais gerais da poética de Poe, que envolvem efeito, tom narrativo e tema, servem de base para Cortázar compor seus próprios capítulos a respeito de aspectos do conto. Agora, a base é sua própria experiência como contista. Em conferência realizada para escritores cubanos, o autor de $O$ jogo da amarelinha (CORTÁZAR, 2008, p. 148) classifica quase todos os contos de sua autoria como pertencentes ao gênero fantástico, pois são textos que se opõem a um equivocado realismo, que consiste em crer que todas as coisas podem ser descritas e explicadas, conforme certas premissas impostas pelas escolas científico filosóficas do século XIX. Cortázar (2008, p. 148) ainda cita Alfred Jarry, seu orientador em uma busca pessoal por um realismo à margem da ingenuidade, para quem o verdadeiro estudo da realidade reside na exceção das leis, e não nos momentos em que elas se cumprem.

Sobre as características gerais das narrativas fantásticas, cabe lembrar as palavras de Todorov. O crítico (TODOROV, 2013, p. 148) escreve que, no mundo tal qual o conhecemos, universo esse em que, a princípio, não existem seres sobrenaturais, 
o fantástico se insere como um fato que não pode ser esclarecido pelas leis desse planeta. O indivíduo que vivencia o insólito deve escolher entre duas opções - ou foi vítima de uma distorção de seu

s próprios sentidos e tudo à sua volta permanece como está ou houve realmente o ocorrido, mas de uma maneira que não é sabida pela personagem. Tendo ciência sobre qual das opções melhor se encaixa na narrativa, migra-se do fantástico para o estranho ou para o maravilhoso. Ainda de acordo com o autor de As estruturas narrativas (TODOROV, 2013, p.148), o fantástico seria, assim, a hesitação e a incerteza experimentada por um indivíduo durante certo período.

É justamente como uma síntese do indizível, do inexplicável ou do incerto que Cortázar enxerga o conto. Ele (CORTÁZAR, 2008, p. 150) analisa que o conto é resultado do embate entre vida e expressão escrita, em que a forma breve se coloca como um resumo de uma biografia abreviada, algo súbito e fugaz como um tremor de água dentro do cristal. Dialogando com o conceito trazido por Victor Chklóvski (2013, p. 83), Cortázar (2008, p. 150) conclui que essa alquimia secreta e quase invisível só pode ser revelada por meio de imagens, e elas só podem ser captadas por observadores perspicazes. Como sabemos, a observação e o distanciamento são práticas comuns entre artistas. Por isso, James Wood (2017, p. 50) escreve que pessoas comuns não olham com vagar para as coisas que as rodeiam, mas os artistas em geral olham.

Entre esses observadores, os bons fotógrafos têm grande destaque. Empunhando suas objetivas, estão sempre atentos ao que se passa à sua volta. Muitas vezes, dispõem de uma fração de segundo para compor o cenário de suas obras. Cortázar, que também era fotógrafo, foi um escritor que muito refletiu sobre a prática da fotografia. No conto “As babas do Diabo", seu narrador (CORTÁZAR, 2016, p. 59) diz que as pessoas deveriam, ainda crianças, aprender a fotografar. Assim, desenvolveriam senso crítico e capacidade de fazer recortes da realidade, de adotar diversos ângulos de visão.

Ao refletir sobre os modos de escrever contos, Cortázar imagina o contista como um tipo de fotógrafo. Nesse sentido, ele (CORTÁZAR, 2008, p. 151) compara o romance ao cinema e o conto à fotografia. As narrativas romanescas se aproximariam da sétima arte na medida em que ambas pressupõem uma ordem aberta de desenvolvimento do enredo. Já o conto e a fotografia pressupõem um limite de abordagem que é imposto pelo recorte da lente. Tal limitação é utilizada como fator 
estético por fotógrafos e escritores - no caso desses últimos, como já vimos pelas palavras de Charles Kiefer (2011, p. 18-19), foi uma condição imposta pelo restrito espaço em jornais e revistas e pela necessidade de se ler uma história em breve espaço temporal. Essa situação transformou o escritor de contos, escreve Alfredo Bosi (2006, p. 9), em um pescador de momentos singulares e cheios de significação. O contista descobre o que os outros não sentiram com tanta acuidade, não viram com a clareza necessária, explorando, por meio do discurso literário, uma hora intensa e aguçada da percepção.

Sobre a função da fotografia, Cortázar (2008, p. 151) escreve que fotógrafos da estirpe de Cartier-Bresson definem seu trabalho como a arte paradoxal de recortar fragmentos da realidade e, ao mesmo tempo, atribuir-lhes significados que transcendam os limites impostos pelos visores de suas câmeras. Assim, tanto fotógrafos quanto contistas são caçadores de acontecimentos significativos, momentos que direcionem a sensibilidade do espectador/leitor para algo muito além da imagem projetada. É o que Roland Barthes (2015, p. 14) chama de particular absoluto, evento que a fotografia reproduz infinitamente e que ocorreu somente uma vez, algo que nunca mais se repetirá.

Dessa maneira, pensando no efeito (aqui, mais uma referência à poética de Poe) buscado pelas narrativas curtas, Cortázar (2008, p. 151-152) compara o ato de ler a uma luta de boxe. Assim, romance ganha do leitor por pontos, acumulando progressivamente os efeitos a cada episódio. Já o conto deve ser incisivo e mordente desde o início. Ainda que não pareça tão intenso, o bom contista, explica Cortázar (2008, p. 152), comporta-se como um boxeador experiente que, de maneira sutil, enfraquece a defesa do adversário até nocauteá-lo com um cruzado fulminante. Ao contrário do romancista, o escritor de contos não possui tempo para acumular pontos e por isso deve trabalhar de maneira vertical, em profundidade.

A respeito do tema que recheia as narrativas, Cortázar se apropria de reflexões que já haviam aparecido em seu ensaio sobre o Poe contista, mas, naquela ocasião, apenas como leitura do que o escritor estadunidense esperava de um bom conto. $\mathrm{O}$ argentino (CORTÁZAR, 2008, p. 152) ressalta que uma narrativa breve não se torna ruim pela temática, mas pelo tratamento linguístico ao qual é submetida. Ou seja: não é $o$ que se diz, mas como. Desde as primeiras palavras, é necessário que três pontos 
cruciais identificados por Cortázar no interior do mecanismo das narrativas curtas apresentem-se ao leitor: significação, intensidade e tensão.

O idealizador da Valise de cronópio (CORTÁZAR, 2008, p. 152-153) explica que a escolha do tema faz com que o conto se torne significativo. Assim como o bom fotógrafo (vide a imagem de Robert Capa por nós destacada) congela uma cena polissêmica, contistas como Mansfield e Tchekhov selecionam pequenas tramas cotidianas e familiares que, depois de representadas por apurados meios expressivos, vão além da miserável existência que as define. A ideia de significação, continua Cortázar (2008, p. 153), não encontra funcionalidade se não estiver organicamente relacionada com a intensidade e a tensão, elementos que dialogam de maneira direta com o tratamento literário e a técnica narrativa.

No ensaio "Do conto breve e seus arredores", o escritor argentino (CORTÁZAR, 2008, p. 228) trata particularmente da tensão, dissertando a respeito do caráter esférico do conto. Toda a ação do narrador responsável pelo relato deve convergir para os acontecimentos que estejam dentro desse espaço circunscrito, desenvolvendo a trama do interior para o exterior. Esse raciocínio conversa com a escrita de Edgar Allan Poe, à qual nos referimos anteriormente, quando o autor identifica como literariamente fracos os textos alegóricos de Hawthorne.

Portanto, pode-se dizer que, dentro desse universo único, algo se rompe, acontecimento ou revelação inexplicável que balança suas estruturas.

\section{BREVES CONSIDERAÇÕES}

No início deste trabalho, vimos como a arte de contar histórias, desde os seus primórdios relacionados à oralidade e a rituais sagrados, esteve ligada à singularização de imagens, ou seja, à maneira peculiar como fatos são narrados. Além da forma, também é importante que certa dramaticidade seja criada, situação que culmina em desfecho catártico.

No século XIX, o advento da imprensa trouxe consigo a dessacralização das narrativas orais e a questão da autoria. Os periódicos tinham a necessidade de não somente informar, mas também de entreter leitores que buscavam distração nos 
momentos de descanso. Porém, o espaço limitado das páginas impôs aos escritores a obrigação de atentarem-se para a linguagem, que deveria ser sucinta e impactante.

Edgar Allan Poe foi um dos primeiros a notar tal demanda. Fora o polimento da sintaxe, Poe enxergou também que as histórias deveriam trazer em seu interior tensão acompanhada de unidade de efeito, desfecho catártico que, à maneira das tragédias gregas, arrebata o espectador. Seguindo os passos de Poe, Julio Cortázar mostra-se atento à forma da narrativa. Para ele, o que importa não é o que se narra, mas como. Em sua opinião, as histórias curtas devem ser intensas e verticais, nocauteando aquele que a lê com um ponto final carregado de catarse. À maneira de Chklóvski, Cortázar também vê a singularização de imagens como aspecto primordial da arte literária. Não à toa, compara o conto à fotografia.

Diante do que foi exposto nesse artigo, é possível perceber que as exigências impostas pelos espaços reduzidos de jornais e revistas impuseram aos escribas um novo padrão estético para o ato de contar histórias. Essas premissas serviram para aumentar o efeito literário de contos bem realizados e para exigir de seus narradores, mais do que técnica narrativa, um olhar apurado que capte momentos singulares.

\section{Referências}

ADORNO, Theodor W. Notas de literatura I. Trad. Jorge de Almeida. São Paulo: Duas Cidades; Editora 34, 2003.

ARISTÓTELES. "Poética”. In: ARISTÓTELES, HORÁCIO, LONGINO. A poética clássica. Trad. Jaime Bruna. São Paulo: Cultrix, 2005. p. 17-52.

BALZAC, Honoré de. A obra-prima ignorada. Trad. Teixeira Coelho. São Paulo: Iluminuras, 2012.

BARTHES, Roland. A câmara clara. Trad. Júlio Castañon Guimarães. Rio de Janeiro: Nova Fronteira, 2015.

BENJAMIN, Walter. "A obra de arte na era de sua reprodutibilidade técnica". In: BENJAMIN, Walter. Magia e técnica, arte e política: ensaios sobre literatura e história da cultura. Trad. Sérgio Paulo Rouanet. São Paulo: Brasiliense, 2012. p. 179212.

BORGES, Jorge Luis. Borges oral \& sete noites. Trad. Heloisa Jahn. São Paulo: Companhia das Letras, 2011. 
BOSI, Alfredo (Org). O conto brasileiro contemporâneo. São Paulo: Cultrix, 2006.

CALVINO, Italo. Por que ler os clássicos. Trad. Nilson Moulin. São Paulo: Companhia das Letras, 2007.

CARONE, Modesto. “O narrador kafkiano e a metáfora”. In: KAFKA, Franz.

Essencial. Trad. Modesto Carone. São Paulo: Penguin Classics Companhia das Letras, 2011. p. 16-19.

CHKLÓVSKI, Victor. “A arte como procedimento”. In: TODOROV, Tzvetan. Teoria da literatura: textos dos formalistas russos. Trad. Roberto Leal Ferreira. São Paulo: Editora Unesp, 2013. p. 83-108.

CORTÁZAR, Julio. Valise de cronópio. Trad. Davi Arrigucci Jr e João Alexandre Barbosa. São Paulo: Perspectiva, 2008.

CORTÁZAR, Julio. As armas secretas. Trad. Eric Nepomuceno. Rio de Janeiro: BestBolso, 2016.

DEZOTTI, Maria Celeste Consolin (Org.). A tradição da fábula: de Esopo a La Fontaine. São Paulo: Editora Unesp, 2018.

GENETTE, Gérard. Figuras III. Trad. Ana Alencar. São Paulo: Estação Liberdade, 2017.

HOUAISS, Antonio; VILLAR, Mauro de Salles. Dicionário Houaiss de língua portuguesa. Rio de Janeiro: Objetiva, 2009.

KON, Noemi Moritz. “Apresentação”. In: MAUPASSANT, Guy de. 125 contos de Guy de Maupassant. Trad. Amilcar Bettega. São Paulo: Companhia das Letras, 2009. p. 928.

LUCAS, Fábio. "O conto no Brasil moderno". In: PROENÇA FILHO, Domício (Org.). O livro do seminário: ensaios. São Paulo: LR Editores, 1983. p. 109-164.

GALVÃO, Walnice Nogueira. "Cinco teses sobre o conto". In: PROENÇA FILHO, Domício (Org.). O livro do seminário: ensaios. São Paulo: LR Editores, 1983. p. 165173.

GOTLIB, Nádia Battella. Teoria do conto. São Paulo: Ática, 1985.

KIEFER, Charles. A poética do conto: de Poe a Borges. São Paulo: Leya, 2011.

MAGALHÃES JR., Raimundo. A arte do conto. Rio de Janeiro: Bloch, 1972.

POE, Edgar Allan. "Primeira resenha de Edgar Allan Por sobre Twice-told tales, de Nathaniel Hawthorne”. In: KIEFER, Charles. A poética do conto: de Poe a Borges. Trad. Charles Kiefer. São Paulo: Leya, 2011. p. 329-332. 
POE, Edgar Allan. "Segunda resenha de Edgar Allan Por sobre Twice-told tales, de Nathaniel Hawthorne". In: KIEFER, Charles. A poética do conto: de Poe a Borges. Trad. Charles Kiefer. São Paulo: Leya, 2011. p. 333-348.

POE, Edgar Allan. "Terceira resenha de Edgar Allan Por sobre Twice-told tales, de Nathaniel Hawthorne". In: KIEFER, Charles. A poética do conto: de Poe a Borges. Trad. Charles Kiefer. São Paulo: Leya, 2011. p. 349-367.

POE, Edgar Allan. “A filosofia da composição”. In: POE, Edgar Allan. O corvo. Trad. Paulo Henriques Britto. São Paulo: Companhia das Letras, 2019. p. 57-74. PROPP, Vladimir. "As transformações dos contos maravilhosos". In: TODOROV, Tzvetan. Teoria da literatura: textos dos formalistas russos. Trad. Roberto Leal Ferreira. São Paulo: Editora Unesp, 2013. p. 271-304.

SÜSSEKIND, Flora. Cinematógrafo de letras. São Paulo: Companhia das Letras, 1987. TODOROV, Tzvetan. As estruturas narrativas. Trad. Leyla Perrone-Moisés. São Paulo: Perspectiva, 2013.

WOOD, James. A coisa mais próxima da vida. Trad. Célia Euvaldo. São Paulo: SESISP Editora, 2017. 